Harvard Kennedy School Misinformation Review ${ }^{1}$

May 2020, Volume 1, Special Issue on COVID-19 and Misinformation

Creative Commons Attribution 4.0 International ( $\underline{\text { CC BY 4.0) }}$

Reprints and permissions: misinforeview@hks.harvard.edu

DOI: https://doi.org/10.37016/mr-2020-018

Website: misinforeview.hks.harvard.edu

\title{
Signs of a new world order: Italy as the COVID-19 disinformation battlefield
}

When Italy became the western center of the COVID-19 outbreak, it also became the focus of a series of states-sponsored coordinated disinformation campaigns. From early March through May 2020, disinformation operations in the country have increased noticeably, showing evidence of evolving strategies from multiple state actors geared towards reshaping the narrative of the global COVID-19 crisis and pushing forward geopolitical interests. Such campaigns may be a sign of things to come with Italy as a critical battleground subject to state-sponsored disinformation operations, acting as a gauge of power relations particularly between the United States, Russia, the EU, and China.

Author: Costanza Sciubba Caniglia

Affiliation: HKS Misinformation Review, Harvard University, USA

How to cite: Sciubba Caniglia, C. (2020). Signs of a new world order: Italy as the COVID-19 disinformation. Harvard Kennedy School (HKS) Misinformation Review, 1(3).

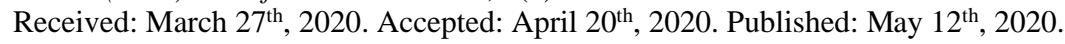

\section{Italy at the center of the outbreak}

On March $9^{\text {th }}, 2020$, following the outbreak of COVID-19 cases in Codogno, a small village in the northern region of Lombardy, Italy became the first western country to implement a nationwide lockdown (Ebhardt \& Follain, 2020). Images of people fleeing Milan, the country's main business hub, to return to local villages, shocked and worried countries all over the world. With that first measure, Italy effectively became the sandbox tester of prevention measures and "flatten the curve" strategies to control the contagion (Pisano et al., 2020).

At that same moment, Italy not only became a testing field for COVID-19 public health management, but also the front line for misinformation and disinformation campaigns from both internal and external actors, where different regional and international powers could test out their information operations strategies (Barnes et al., 2020). This paper will focus on coordinated disinformation campaigns sponsored by state actors in Italy and explain why Italy is likely to remain an informative point of observation for the evolving geopolitical relations between China, Russia, the EU, and the United States. In particular, I will focus on the role of China and the use of relatively new - for China - propaganda techniques: aid diplomacy, tinfoil-hat diplomacy (DiResta, 2020), and an increased role of its diplomatic and official networks all over the world to shape the narrative.

\footnotetext{
${ }^{1}$ A publication of the Shorenstein Center on Media, Politics and Public Policy at Harvard University's John F. Kennedy School of Government.
} 


\section{A substantial increase of disinformation campaigns}

Since the beginning of the COVID-19 outbreak in Europe, as noted in the Europol report from the $3^{\text {rd }}$ of April 2020, many European states reported problems with respect to the spread of disinformation (Europol, 2020). Disinformation and misinformation around COVID-19 proliferated, with "potentially harmful consequences for public health and effective crisis communication" (ibid., p.4) In this context, some state and state-backed actors have sought to advance geopolitical interests through public health crisis messaging, often by directly challenging the credibility of the EU and its partners. These types of campaigns attacking EU unity are not infrequent; however, they have intensified during the COVID-19 pandemic.

The EU vs Disinfo website, part of the administration of the European External Action Service and focused in particular on pro-Russia disinformation, tracked at least 84 campaigns involving Italy between the $1^{\text {st }}$ of February and the $30^{\text {th }}$ of April $2020 .{ }^{2}$ In the same period in 2019, they only tracked 6 such campaigns. ${ }^{3}$ Not only has there been a notable increase in Russian disinformation campaigns, pro-China campaigns have also increased, oftentimes adopting familiar pro-Russia talking points.

In reviewing these campaigns, the main effort appears to be reframing the narrative related to COVID19 , changing the view of China from "victim of the virus" to an image of China as a strong and responsible moral leader, able to protect its population, and now helping other countries around the world (in the West, in particular) react to the crisis. With Italy being the first European country to suffer from a severe COVID-19 outbreak and already struggling with an increase in the anti-EU sentiment amongst its population, it was the perfect setting for this reframing. Furthermore, these campaigns had all the more potential to be effective because Russian and Chinese interests aligned on this occasion, both having the following goals:

- Changing China's and Russia's narratives, establishing the two countries as benevolent leaders and "helping hands" on the international stage. ${ }^{4}$

- Contrasting these profiles with the supposed "ineffectiveness" of the EU and the United States. In particular, they focused on the alleged refusal of the EU to aid European countries suffering from COVID-19 outbreaks, again with a particular focus on Italy (Momtaz et al., 2020).

\footnotetext{
${ }^{2}$ See https://euvsdisinfo.eu/disinformation-cases/?text=italy $\&$ date $=01.02 .2020+-+30.04 .2020$

${ }^{3} \mathrm{See}$ https://euvsdisinfo.eu/disinformation-cases/?text=italy\&date=01.02.2019+-+30.04.2019

${ }^{4}$ For China, see examples from the government-funded media outlets XinhuaNet, People's Daily Online, and China Daily, http://www.xinhuanet.com/english/2020-03/16/c_138883704.htm, http://en.people.cn/n3/2020/0325/c90000-9672307.html, https://www.chinadaily.com.cn/a/202003/23/WS5e786f9da3101282172814da.html, for Russia see RT and Sputnik https://www.rt.com/russia/483796-russian-military-coronavirus-aid-italy/, https://sputniknews.com/photo/202003231078677989russia-aids-italy-fight-against-covide19-pandemic/, all supporting the narrative of the "helping hands."
} 


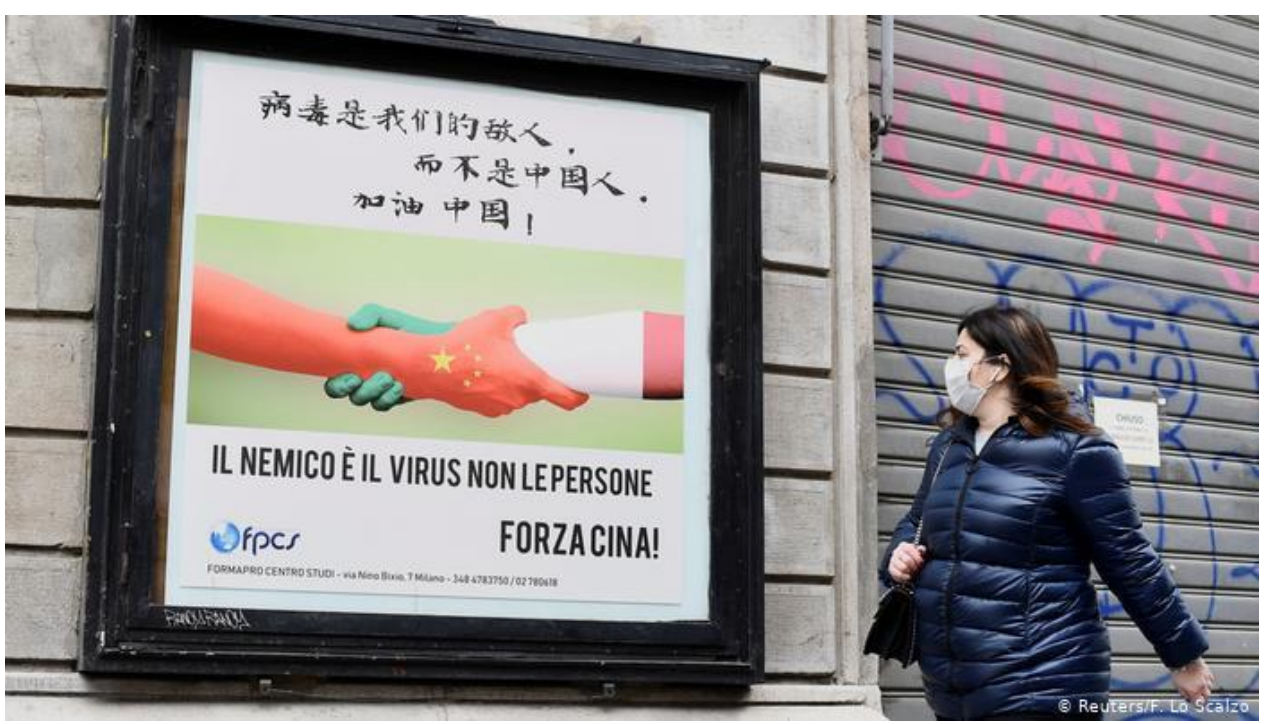

Figure 1. A campaign in Milan's Chinatown neighborhood, in March 2020, showing Italian and Chinese "helping hands" supporting each other. The text reads: The enemy is the virus, not the people.

Delivering aid is a common "charm offensive" strategy that should not be seen as negative per se; however, in the case of COVID-19, it has come as part of a wider and more sophisticated propaganda effort to spin the narrative on the virus response and seize the moment to undermine the EU and the transatlantic alliance.

One peculiar feature of this campaign is that the reframing and disinformation have frequently come from the Chinese official diplomatic network. For example, the spokesperson and Director General of the Information Department of China's Foreign Ministry, Zhao Lijian, speculated on Twitter that the US was hiding early cases of COVID-19, disguising them as regular influenza (Xiao et al., 2020). ${ }^{5}$ Another example is offered by a short animated video shared by the Chinese Ambassador in France on Twitter ${ }^{6}$ in which China criticized the US response to the virus, showing a lying and inconsistent Statue of Liberty attempting to blame China for all of its problems while continuing to get sicker and sicker (Fig.2).

\footnotetext{
${ }^{5}$ See https://twitter.com/zlj517/status/1238114622684585984?s=20

${ }^{6}$ See https://twitter.com/AmbassadeChine/status/1255873178632687622?s=20
} 
Ambassade de Chine en France @ AmbassadeChine · Apr 30 Once Upon a Virus...

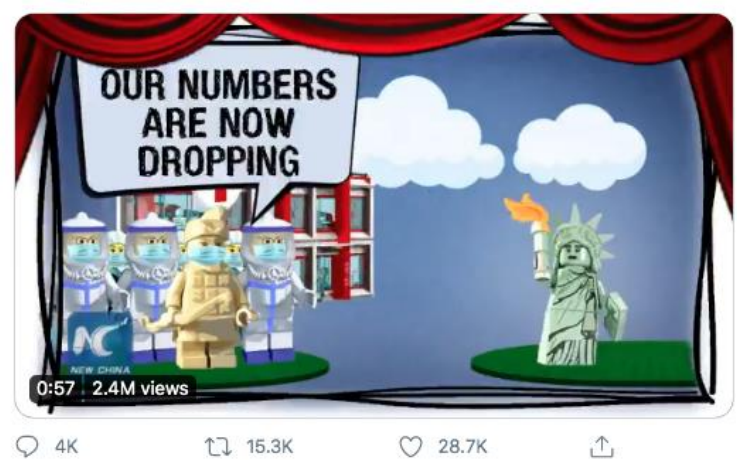

Ambassade de Chine en France $\theta$ @AmbassadeChine

Once Upon a Virus...

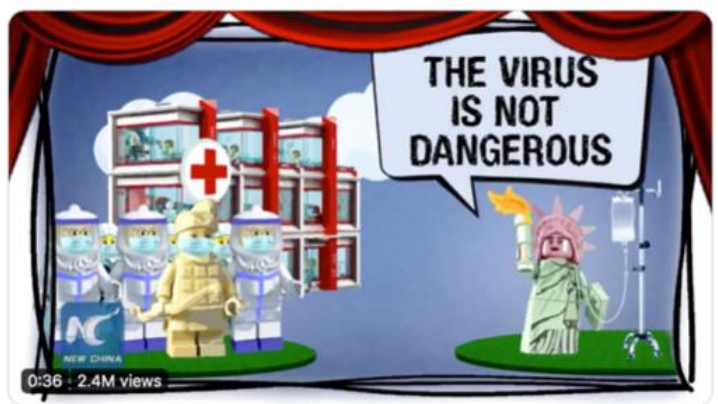

10:54 AM · Apr 30, 2020 - Twitter Web App
Ambassade de Chine en France $\theta$ @AmbassadeChine

Once Upon a Virus...

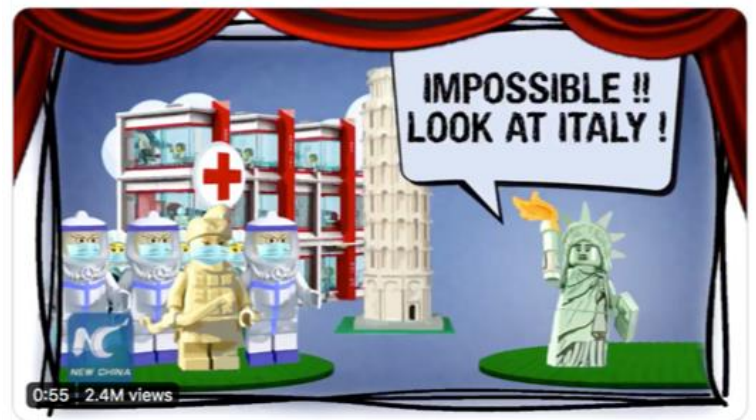

Ambassade de Chine en France $\theta$ @AmbassadeChine

Once Upon a Virus...

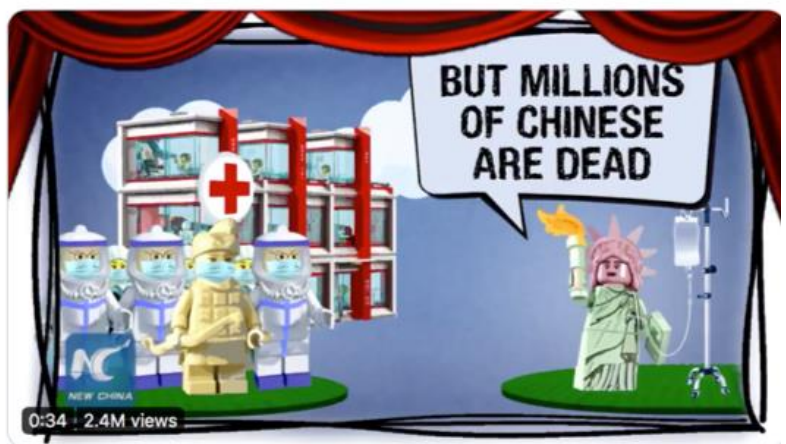

Figure 2: Stills from video shared by the Ambassador of China in France.

With these campaigns, China has also adopted more typically Russian misinformation techniques, like spreading conflicting conspiracy theories. Both China and Russia have worked to not spread a single specific story, but to convey the idea that the truth is unknowable. ${ }^{7}$ And it should be noted that in conjunction with these communications campaigns, Russia has sent military doctors to Italy (Fig. 3), although there have been rumors among the general population that the Russian aid might have also included different types of military assets. Additionally, some of the masks delivered by China were defective and had to be recalled by the Italian health and consumer protection authorities (Del Trentino, 2020; Campbell, 2020).

\footnotetext{
${ }^{7}$ See https://twitter.com/rosenbergerlm/status/1241860407037493251
} 

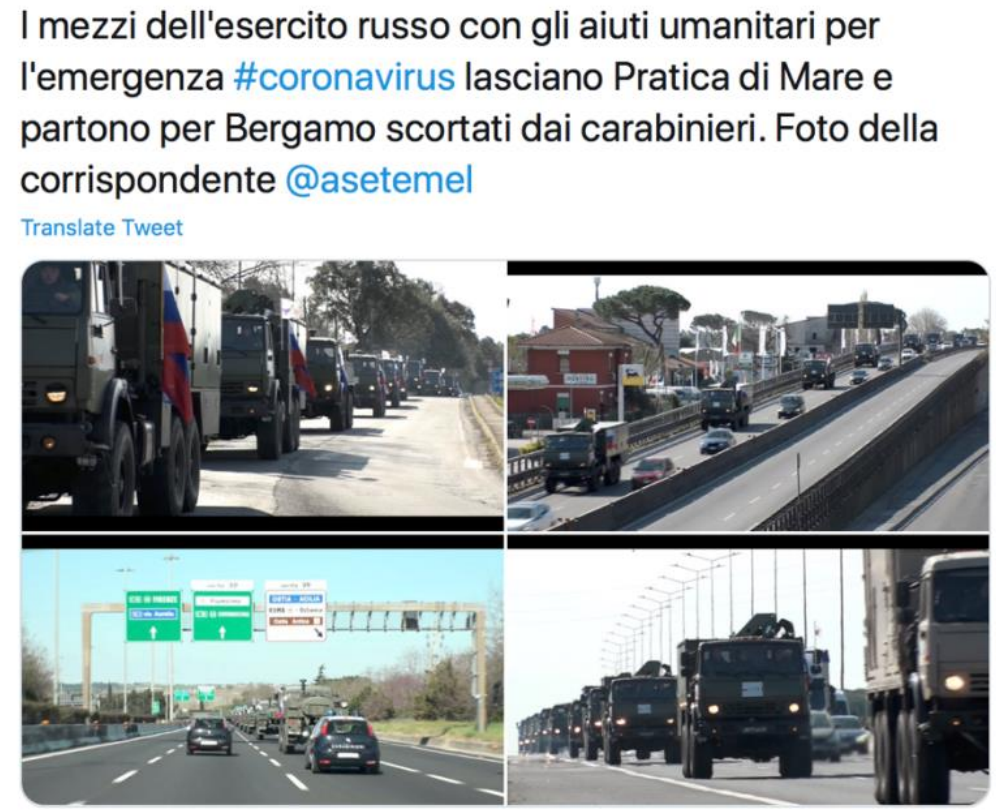

7:12 AM - Mar 25, 2020 - Twitter for Android

Figure 3. Russian military personnel arriving in Italy.

In terms of economic and structural aid though, there has been no comparison between the EU's response and that from China and Russia. The EU alliance has been the overwhelming main source of support for Italy ${ }^{8}$ but the public narrative has not followed these facts. This messaging is not only coming from China or online disinformation networks, but it has also been supported by internal political forces. This is best demonstrated by the Italian Minister of Foreign Affairs, Luigi di Maio, a member of the Euro-skeptic MoVimento 5 Stelle [M5S] party. During an interview on March $24^{\text {th }}$, he declared, "Those who were skeptical of the 'Belt and Road' initiative now must admit that investing in this friendship has allowed us to save human lives."

\section{Why is Italy particularly central for China's narrative in the West?}

Well before COVID-19, Italy had begun to develop a peculiar relationship with China as compared to other EU nations. Under Foreign Minister Di Maio's leadership, for example, Italy sparked criticism across the EU and the US, when in March 2019 it became the first G7 country to sign on to China's 'Belt and Road' initiative, "an investment and infrastructure project" that many fear will allow China undue influence in the region (Ellyatt, 2019).

With the presence of M5S in the government and their anti-establishment platform, they represent a possible opening for China, essential to furthering China's influence in the West. However, they are one of three major parties in the country at the moment, with the other two splitting their loyalties between the transatlantic alliance (the US and the EU) for Partito Democratico [PD] and Russia for Lega (formerly known as Lega Nord per l'Indipendenza della Padania).

\footnotetext{
${ }^{8} \mathrm{See}$ https://ec.europa.eu/ireland/news/summary-of-the-european-commission-s-response-to-corona-virus-covid-19-crisis-todate en

${ }^{9}$ See https://www.youtube.com/watch?v=0W7JRf6qaog
} 
Without a strong, stable coalition currently governing the country (the government today is composed primarily of M5S and PD), Italy presents ideal conditions for an ideological battle between these three forces. While the transatlantic alliance is not openly challenged by any of these parties, allies, in particular the United States, are increasingly vigilant of Italy's new openness to China and Russia. Similar to what happened during the Cold War where Italy's two main parties (Democrazia Cristiana, DC, and Partito Comunista Italiano, PCI) were strictly connected with the two opposing powers (the US and the USSR, respectively), Italy might once again recreate international tensions within its borders as the quintessential territory to see play out a new geopolitical power struggle.

\section{Conclusions}

In this politically fluid moment though Italy remains a fundamental member of the Transatlantic alliance, of the G7, and of NATO, serving as host country for five US military bases and for NATO bases. Its departure from these alliances may mean their dissolution, especially if it happened in conjunction with Italy's departure from the EU. Being a pillar with signs of vulnerability and receptiveness to appeals made by China, Italy will be critical to China's geopolitical efforts in the West. And there is a chance that the COVID19 pandemic could provide the perfect excuse to accelerate the shift in power and influence from West

to East. In the words of scholar Stephen Walt: "The response in Europe and America has been slow and haphazard by comparison, further tarnishing the aura of the Western 'brand'" (Burns et al., 2020).

This all might lead to a retreat from hyper-globalization, as citizens look to national governments to protect them and reduce future vulnerabilities. Much will depend on the development of relations between the United States and China (as well as with the EU and Russia). With its distinct geopolitical and geographical positioning, and because of its tensions with the EU and its particularly devastating COVID19 outbreak, Italy has been and will likely remain central to the ongoing geopolitical struggle.

\section{Bibliography}

Barnes, J. E., Rosenberg, M., \& Wong, E. (2020, March 28). As virus spreads, China and Russia see openings for disinformation. The New York Times. https://www.nytimes.com/2020/03/28/us/politics/china-russia-coronavirusdisinformation.html

Burns, N., Nye, J. S., \& Walt, S. M. (2020, March 20). How the world will look after the coronavirus pandemic. Belfer Center for Science and International Affairs. https://www.belfercenter.org/publication/how-world-will-look-after-coronavirus-pandemic

Campbell, C. (2020, April 3). Why China's 'mask diplomacy' is faltering. Time. https://time.com/5814940/china-mask-diplomacy-falters/

Del Trentino, C. (2020, April 17). Le mascherine cinesi difettose, scatta il maxi sequestro dei Nas. Codacons. https://codacons.it/le-mascherine-cinesi-difettose-scatta-il-maxi-sequestro-dei-nas/

DiResta, R. (2020, April 11). For China, the 'USA Virus' Is a geopolitical ploy. The Atlantic. https://www.theatlantic.com/ideas/archive/2020/04/chinas-covid-19-conspiracytheories/609772/

Ebhardt, T. \& Follain, J. (2020, May 9). Italy goes into nationwide lockdown as virus numbers spiral. Bloomberg. https://www.bloomberg.com/news/articles/2020-03-09/italy-to-extend-lockdownnationwide-after-virus-spreads

Ellyatt, H. (2019, March 28). Is Italy playing with fire when it comes to China? CNBC. https://www.cnbc.com/2019/03/27/italys-joins-chinas-belt-and-road-initiative.html 
Europol (2020). Catching the virus cybercrime, disinformation and the Covid-19 pandemic. Europol. https://www.europol.europa.eu/print/publications-documents/catching-virus-cybercrimedisinformation-and-covid-19-pandemic

Momtaz, R., Burchard, H. von der, \& Moens, B. (2020, April 29). Beijing doubles down in EU propaganda battle. Politico. https://www.politico.eu/article/beijing-doubles-down-in-eu-propaganda-battle/

Pisano, G. P., Sadun, R., \& Zanini, M. (2020, March 27). Lessons from Italy's response to coronavirus. Harvard Business Review. https://hbr.org/2020/03/lessons-from-italys-response-to-coronavirus

Xiao, M., Jordan, D., Felling, M., \& Koettl, C. (2020, March 18). How China Is reshaping the coronavirus narrative. The New York Times.

https://www.nytimes.com/video/world/asia/100000007024807/china-coronaviruspropaganda.html?playlistld=video/coronavirus-news-update 


\section{Copyright}

This is an open access article distributed under the terms of the Creative Commons Attribution License, which permits unrestricted use, distribution, and reproduction in any medium, provided that the original author and source are properly credited. 